\title{
Meningkatkan Kemampuan Membaca Bagi Peserta Didik Tunanetra
}

\author{
Winda Yulfani* \\ E-mail: yulfaniwinda@gmail.com \\ Program Studi Pendidikan Bahasa dan Sastra Indonesia, Universitas Maritim Raja Ali Haji, Kepulauan Riau, Indonesia
}

\begin{abstract}
Abstrak
Penelitian ini bertujuan untuk mengetahui bagaimana meningkatnya kemampuan membaca bagi peserta didik yang mengalami tunanetra. Adapun penelitian ini berfokus kepada 1) Kemahiran Membaca 2) Peserta Didik Tunanetra. Anak yang mengalami tunanetra memungkinkan sangat berpotensi agar bisa lebih termotivasi belajar membaca. Di mana seperti yang kita ketahui bahwa anak yang mengalami tunanetra kehilangan salah satu indera utama mereka yaitu daya penglihatan sehingga dalam akan susah dalam mengikuti proses belajar mengajar. Maka dari itu bagi peserta didik yang mengalami tunanetra membaca dapat dilakukan dengan media Braille maupun audio.
\end{abstract}

Kata kunci: Kemampuan Membaca, Peserta Didik, Tunanetra.

\section{PENDAHULUAN}

Keterampilan membaca adalah kemampuan yang sangat penting dalam kehidupan kita karena seperti yang kita ketahui bahwasanya pengetahuan diperoleh melalui membaca, dan mengingat. Keterampilan membaca merupakan fondasi bagi seseorang dalam memperoleh pengetahuan, keterampilan, dan pembentukan sikap. Oleh karena itu, keterampilan membaca harus benar-benar dikuasai oleh peserta didik dengan baik sejak dini. Membaca untuk menambah pengetahuan dengan sumber bacaan mana saja memang sangat bagus, dan lebih baik dari pada tidak membaca sama sekali. Hanya saja bahan bacaan yang didapatkan dari internet belum tentu benar, apalagi yang belum diketahui penulisnya. Kebenaran suatu informasi adalah sebuah pertanggungjawaban yang harus tahu kebenarannya, seperti sumber tulisan terkadang tidak tercantum dalam internet sehingga menyebabkan bacaan tersebut sulit dipastikan kebenarannya.

Bagi peserta didik yang mengalami tunanetra membaca dapat dilakukan dengan media Braille maupun audio. Menurut kemendikbud (2015) agar pelaksanaan literasi bagi peserta didik dengan hambatan penglihatan dapat berjalan dengan baik ada dua hal yang harus diperhatikan, yaitu ketersediaan sarana dan prasarana serta aktivitas pembelajaran. Bums et al dalam Rahim 2007, hlm. 20 mengemukakan bahwa kemampuan membaca dan menulis merupakan sesuatu yang vital dalam suatu masyarakat terpelajar, namun anak - anak yang tidak memahami pentingnya belajar membaca tidak akan termotivasi untuk belajar. Demikian 
juga pada anak tunanetra yang berpotensi untuk lebih termotivasi belajar membaca. Seperti yang kita ketahui bahwa anak tunanetra kehilangan salah satu indera utama yaitu daya penglihatan sehingga dalam mengikuti proses belajar mengajar khususnya membaca dan menulis Braille diperlukan pelayanan khusus sesuai dengan kondisi anak yang mengalami kebutaan untuk membantu kelancaran belajar membaca dan menulis Braille diperlukan media atau alat bantu yang bisa memberikan pengalaman bermakna dan membentuk pemahaman bagi diri anak.

Anak dengan gangguan penglihatan mempunyai hambatan berbahasa dari sisi perolehan konsep (Elster.1983 dalam Pujaningsih 2010, hlm.20). Hal tersebut dapat dipahami bila meninjau perkembangan bahasa mereka. Pada awal perkembangan bahasa, anak dengan gangguan penglihatan mencapai tahap echolalia seperti anak-anak pada umumnya namun setelah umur satu tahun mereka hanya mampu menirukan kata tanpa mengetahui makna kata yang diucapkannya.

\section{HAKIKAT KEMAMPUAN MEMBACA}

Kemampuan membaca merupakan sebuah dasar yang dilakukan untuk menguasai berbagai bidang studi atau berbagai pelajaran. Jika pada usia anak yang masih sekolah permulaan kemampuan membaca tidak dimiliki atau dikuasai maka kedepannya akan mengalami banyak kesulitan dalam mempelajari berbagai bidang pelajaran atau studi pada kelas-kelas berikutnya. Maka dari itu kemampuan membaca sangatlah penting bagi peserta didik agar mereka bisa dengan mudah untuk memahami ilmu pengetahuan lainnya. Seperti yang kita ketahui membaca itu bukanlah suatu kegiatan yang berdiri sendiri tetapi membaca membutuhkan berbagai proses sintesis yang tergabung dalam suatu sikap pembaca yang aktif.

Di mana proses membaca itu merupakan proses psikologi yang mencakup sebuah intelegensi, jenis kelamin, usia, mental, tingkat sosial, ras, bahasa, dan ekonomi, serta kemampuan persepsi. Membaca juga disebut sebagai proses sensori di mana dimulai dari penggunaan sebuah indera, tidak hanya itu membaca juga disebut sebagai proses perseptual yang mana merupakan sebuah respons dan stimulus yang menghubungkan sebuah makna dan lambang. Membaca sebagai sebuah proses perkembangan di mana akan terjadi sepanjang hayat. Dan selanjutnya membaca sebagai sebuah proses perkembangan keterampilan yaitu kemampuan membaca yang objektif, bertahap merupakan perkembangan konsep dan identifikasi serta interpretasi terhadap suatu informasi (Subrata, 2010).

Keterampilan membaca adalah kemampuan yang sangat penting dalam kehidupan kita karena di mana seperti yang kita ketahui bahwasanya pengetahuan itu diperoleh melalui dari 
membaca, dan juga mengingat. Keterampilan membaca juga merupakan suatu fondasi bagi seseorang untuk memperoleh suatu pengetahuan, keterampilan, dan juga pembentukan sikap. Adanya keterampilan membaca ini membuat kita akan sangat mudah mendapatkan suatu informasi yang kita cari.

\section{SARANA PENDUKUNG}

\section{a. Pengertian Peserta Didik}

Peserta didik merupakan seorang anak yang belum dewasa atau masih di bawah umur yang memiliki potensi dasar yang masih harus dikembangkan. Peserta didik merupakan makhluk hidup yang mempunyai ciri-ciri kepribadian yang macam-macam sesuai dengan masa pertumbuhan dan perkembangan mereka. Di mana pertumbuhan dan perkembangan itu di pengaruhi oleh lingkungan peserta didik itu masing-masing di mana tempat mereka berada. Peserta didik juga merupakan anggota dari masyarakat yang sedang berusaha mengembangkan potensi diri mereka dengan melalui proses pembelajaran yang sudah tersedia pada jenis dan jalur yang sudah ditentukan masingmasing.

Peserta didik juga sebagai komponen yang tidak bisa dilepas dari sebuah sistem pendidikan sehingga dikatakan bahwa peserta didik itu merupakan sebuah objek pendidikan tersebut. Jadi dari beberapa pengertian di atas dapat di definisikan bahwa anak yang belum mempunyai atau memiliki kedewasaan dan masih memerlukan orang lain untuk mendidik mereka sehingga bisa menjadi seseorang yang dewasa dan memiliki sebuah aktivitas dan kreativitas mereka sendiri.

Peserta didik yang mengalami tunanetra mempunyai masalah atau hambatan dalam meningkatkan pemahaman berbagai konsep dalam pembelajaran sehingga peserta didik tunanetra perlu pembelajaran yang tepat dan benar agar bisa meningkatkan kemampuan membaca bagi peserta didik itu sendiri. Sebagaimana yang sudah dijelaskan oleh Elster di mana anak yang memiliki gangguan penglihatan akan mempunyai hambatan atau masalah berbahasa dari sisi pemerolehan konsep. (Elster. 1983 dalam Pujaningsih 2010, hlm.20).

\section{b. Huruf Braille}

Menurut Anwar Yasin (1979:126-137) media kartu huruf adalah media yang dibuat dari sebuah kertas karton yang ditempelkan atau dituliskan. Kartu tersebut dapat 
dibuat dengan ukuran besar maupun kecil. Huruf Braille merupakan huruf yang tersusun berdasarkan kombinasi pola enam titik timbul, atau masing-masing huruf diwakili dengan beberapa titik. Posisi titik huruf braille ini adalah tiga titik vertikal dan dua titik horizontal. Setelah itu titik-titik tersebut diberi nomor tetap, artinya titik satu, titik dua, titik tiga, titik empat, titik lima, dan titik enam.

Demikian untuk anak yang mengalami tunanetra memungkinkan sangat berpotensi agar bisa lebih termotivasi belajar membaca. Di mana seperti yang kita ketahui bahwa anak yang mengalami tunanetra kehilangan salah satu indera utama mereka yaitu daya penglihatan sehingga dalam akan susah dalam mengikuti proses belajar mengajar. Maka dari itu bagi peserta didik yang mengalami tunanetra membaca dapat dilakukan dengan media Braille maupun audio. Orang yang mengalami ketunanetraan akan membawa dampak atau pengaruh yang sangat besar. Seperti yang sudah di jelaskan oleh Sunanto (2005) dampak atau pengaruh dari ketunanetraan peserta didik dikelompokkan pada fungsi kognitif, Mobilitas, pengembangan bahasa, dan juga keterampilan sosial.

\section{c. Hambatan Peserta Didik Tunanetra dalam Meningkatkan Kemampuan Membaca}

Berhubungan dengan membaca, dampak yang dialami oleh ketunanetraan cukuplah besar. Salah satunya yaitu pada fungsi kognitif yang menyebabkan terganggunya pemerolehan informasi karena dari informasi yang kita perolehi selama ini sebagian besar yaitu dari penglihatan. Pada peserta didik yang normal mungkin aktivitas membacanya tidak mengalami hambatan atau masalah apa pun. Di saat mereka memulai aktivitas membaca mereka juga akan langsung dapat menerima informasi dengan jelas dan dapat mengamati seluruh teks bacaan yang mereka baca. Peserta didik yang norma akan langsung bisa mencari atau menemukan ide pokok atau kalimat yang mereka butuh kan dengan mudah dan juga cepat tanpa membaca sumber bacaan itu dari awal. Bagi peserta didik yang mengalami tunanetra aktivitas membacanya sangatlah berbeda dengan peserta didik yang normal. Mereka harus membaca dari awal paragraf untuk menemukan informasi yang mereka cari atau mereka butuh kan.

Mengamati dengan hati-hati pada setiap teks dan juga huruf dengan cara meraba. Proses membaca yang dilakukan para peserta didik tunanetra cukuplah lama seperti pada satu kata saja pada sebuah bacaan memerlukan waktu yang cukup lama 
apalagi untuk membaca sebuah sumber bacaan yang panjang maka akan membutuhkan waktu yang sangat lama. Berhubungan dengan membaca, peserta didik tunanetra akan tetap mendapatkan informasi yang mereka inginkan melalui kegiatan membaca yaitu dengan menggunakan huruf Braille. Untuk lebih meningkat kemampuan membaca peserta didik yang mengalami tunanetra maka diberikan latihan-latihan seperti drialtaktual. Di mana latihan tersebut sangat berguna untuk melatih kepekaan peserta didik tunanetra dengan jari-jari dalam meraba huruf-huruf Braille. Latihan drial-taktual ini menggunakan pemanfaatan yaitu tusing Braille yang mana diterapkannya ternyata sangat mampu untuk meningkatkan kemampuan membaca peserta didik yang mengalami tunanetra.

\section{KESIMPULAN}

Kesimpulan yang bisa diambil untuk meningkatkan kemampuan membaca bagi peserta didik tunanetra yaitu dengan diberikan latihan-latihan seperti drial-taktual. Di mana latihan tersebut sangat berguna untuk melatih kepekaan peserta didik tunanetra dengan jari-jari dalam meraba huruf-huruf Braille. Latihan drial-taktual ini menggunakan pemanfaatan yaitu tusing Braille yang mana diterapkannya ternyata sangat mampu untuk meningkatkan kemampuan membaca peserta didik yang mengalami tunanetra.

Saran dari peneliti supaya peserta didik tunanetra bisa lebih meningkatkan kemampuan peserta didik tunanetra lebih meningkat juga dibutuhkan didikan atau dukungan dari pendidik dan orang tua peserta didik. Dilakukan berbagai pengamatan yang lebih luas pada peserta didik tunanetra.

Diharapkan untuk peneliti selanjutnya mampu menemukan solusi yang lebih efektif dan juga efisien dalam meningkatkan kemampuan membaca bagi peserta didik tunanetra.

\section{REFERENSI}

Triwiaty, R. \& Assjari, M. (2017). Program Literasi Sekolah untuk Meningkatkan Kemampuan Membaca Siswa Tunanetra SDLB di SLB Cimahi. Jassi Anakku, 18(2), 51-56. https://ejournal.upi.edu/index.php/jassi/article/view/9697

Isnaini, B. (2013). Meningkatkan Kemampuan Membaca Permulaan Tulisan Braille Melalui Sistem Menggold bagi Anak Tunanetra. Jurnal ilmiah pendidikan khusus, 1(1), 22-32. http://ejournal.unp.ac.id/index.php/jupekhu

Ramli, M. (2015). Hakikat Pendidik dan Peserta Didik. Tarbiyah Islamiyah, 5(1), 61-84. http://jurnal.uin-antasari.ac.id/index.php/tiftk/article/view/1825

Sattria, R. (2012). Meningkatkan Kemampuan Mengenal Huruf Braille Melalui Media Kartu Huruf Anak Tunanetra. Jurnal ilmiah pendidikan khusus, 1(3), 332-343. http://ejournal.unp.ac.id/index.php/jupekhu 
*Data Penulis

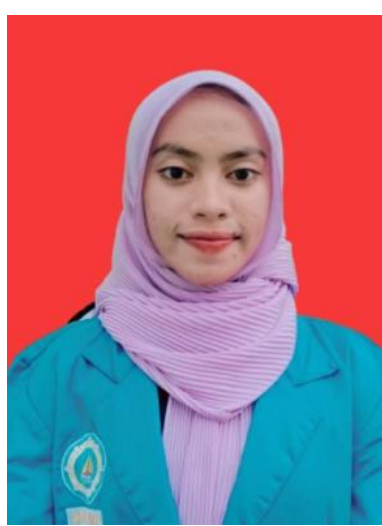

Winda Yulfani, lahir di Tanjung Batang, 14 Juli 2000.

Tamatan SMA Negeri 1 Bunguran Timur tahun ajaran 2018/2019. Pada tahun 2019, Ia melanjutkan studi pada strata satu Program Studi Pendidikan Bahasa dan Sastra Indonesia FKIP Universitas Maritim Raja Ali Haji melalui jalur SNMPTN (Seleksi Nasional Masuk Perguruan Tinggi Negeri).

Kontak:

$\mathrm{Hp} / \mathrm{WA}:-$

Email : yulfaniwinda@gmail.com 